\title{
Reinventing Appropriate Strategies for Curriculum Development and Implementation in Technical Vocational Education and Training in Nigeria for Global Competitiveness
}

\author{
Jane Itohan Oviawe ${ }^{1}$, Agnes Omokhekpe Anetekhai ${ }^{2}$ \\ ${ }^{1}$ Department of Vocational and Technical Education, Ambrose Alli University, Ekpoma, Edo State, Nigeria \\ ${ }^{2}$ Federal Polytechnic, Auchi, Edo State, Nigeria \\ janeoviawe@aauekpoma.edu.ng, janeoviawe98@gmail.com, anetekhaiagnes@gmail.com
}

\begin{abstract}
Technical Vocational education and Training (TVET) has been accepted the world over as a vital tool for achieving sustainable development and global competitiveness. However, TVET in Nigeria are faced with enormous issues such as inadequate funding, inadequate human resources, poor infrastructural facilities, among others which are militating against TVET as a means of achieving sustainable development and global competitiveness. Towards addressing these issues, there is need to embrace global partnership for quality TVET. Hence, this paper examines the concept of TVET, the teaching structure of TVET under the Nigerian Education system with a view to reinventing appropriate strategies for development and implementation of an effective curriculum that will bring about qualified and well trained professionals of for sustainable national development and global competitiveness.
\end{abstract}

Keywords: TVET, Curriculum Development, Public-Private Partnership, Global Competitiveness.

\section{Introduction}

Nigeria is blessed with natural resources. Despite these resources, Nigeria is faced with unemployment, poverty, social and economic instability, underdevelopment, poor quality of education, amongst others. Researchers have stated ways of addressing these issues through knowledge driven economy and skill acquisition in Technical Vocational Education and Training (TVET). TVET is a driving force for the socioeconomic growth and technological development of nations as its focus is oriented towards the workplace and its curriculum emphasizes on the acquisition of employable skills. TVET seen worldwide is globally recognized for its part in preparing individuals with skills to excel in a dynamic work environment (Oviawe, 2018). TVET prepares individuals to work in areas which require very specific skills in trades which are often of practical nature. The International Labour Organization (ILO) recommendation of 2000 and the United Nations Educational Scientific and Cultural Organization (UNESCO) on TVET for the 21st century defined TVET as: (i) a means to facilitate the alleviation of poverty; (ii) a mechanism to promote the environment for sustaining development; (iii) a part of long time learning and preparing; (iv) a way to prepare for world of work and occupational fields; (v) an integral part of general education (Oviawe, Uwameiye \& Uddin, 2018). The definitions above indicate that the overall goal of TVET is to instil the right attitude, develop skills and knowledge which is required to enter and progress in any workplace. TVET is the education whereby people acquire skills and provide them better access to employment and income. British Council (2017) defined TVET as education geared towards the training of low-level manpower, such as, operative, artisans.

Craftsmen and master craftsmen for commerce, industry, agriculture, and ancillary services it concerns the attainment of skills and knowledge needed in organizations to enhance the opportunity for sustainable livelihoods, socio economic development, personal empowerment and production work in every day dynamic environments. From the above definitions of TVET, the words skills and knowledge occupy the centre stage. This means that TVET is an instrument for skills and knowledge to assist its recipients to become useful to the society in which they live. The objectives of TVET in Nigeria are to: (i) provide trained manpower in applied science, technology and business particularly at craft, advance craft and technical levels; (ii) provide the technical knowledge and vocational skills necessary for agricultural, industrial, commercial and economic development; (iii) give training and impart the necessary skills leading to individuals be shall be self-reliant economically; (iv) provide people who can apply scientific knowledge to the improvement and solution of environmental problems for the use and convenience of man; and (v) give introduction to professional studies in engineering and other technologies (Federal Republic of Nigeria (FRN), 2013). Technical vocational education and training prepare individuals for careers with practical or manual operations, which is traditionally not academic related and specific to a particular trade, vocation or occupation. The programme specialise in entry into highly defined occupations. A very important role of education in general, as observed 
by Ezenwafor (2015) is the preservation and updating of knowledge and skills of students in line with changes in the society.

Concept of Curriculum Development: A curriculum is a set of courses constituting an area of specialization offered by an educational institution (Merriam-Webster dictionary). It is heart of any learning institution, which means that schools, polytechnics, universities or any academic institution cannot exist without a curriculum. With its importance in formal education, the curriculum has become a dynamic process due to the changes that occur in the society. Eya (2006) defined curriculum as the sum of experiences learned by people in society as well as school. The curriculum is referred to as a systematic, progressive, purposeful and planned process desired to improve the educational system in its entirety. The society is dynamic; this implies that there are changes or developments happening around the world continuously, the school curricula are affected. Thus, there is a need to update them continuously to address the societal needs (Alvior, 2014). This is combined with fighting the unceasing nature of violence and a steady decline in citizens' living standards. TVET is a form of education that is widely acknowledged as a veritable instrument for commercial and industrial mobilization in any society because it provides the basic trainings needed for industrial development and management. TVET tailors education from merely learning theories in the classroom to actually putting into practice the theories.

Learnt in achieving national needs and job creation for citizens through appropriate curriculum development and implementation in ancient times, people taught their children knowledge and skills to survive by fishing or hunting animal for food. They had no formal education during that time, but their children learnt and acquired the necessary knowledge and skills needed for survival. Hence, they developed their own curriculum that is referred to today as the "Saber-tooth curriculum". This type of curriculum is one where the teaching goal is the knowledge and skills needed for survival. Though, with new inventions and discoveries as a result of development in science and technology, the way of life of the ancient days changed for the better. As a result of this scientific and technological revolution, education became formal, and the development of a specialized curriculum evolved. This curriculum was systematic, well planned and researched, purposeful and progressive. The curriculum was ever evolving to meet up with the changing realities of society through constant reviews and adaptation. Curriculum development as a term has a wide scope due to the fact that it covers the teachers, school and learners. Society's development is also included and the way of life overall. The economy of today shows that development of curriculum play a significant role in enhancement of the economy and its living standards.

It proffers solutions to global problems and condition such as sustainable development, climate change, poverty, politics and environment. A number of processes need to happen for society development to occur. Firstly, developing the curriculum in higher institutions to safeguard the identity of the nation and make sure its socio-economic stability and growth. Therefore, the government of a nation needs a clear cut vision for its people and the nation as a whole. It must establish a national policy objective for the constant review and development of a national curricula plan on the training and acquisition of knowledge and skills needed for the technological development of the nation. It is obvious, that in Nigeria today the importance of TVET and its role in technological advancement is yet to be taken seriously by most Nigerians despite all the enlightenment campaigns and encouragement by the government. TVET plays a pivotal role in the success of any governmental policy which is aimed at local industrialization and technological advancement. Such a policy must envision alleviating poverty, increase food security, literacy ratio, health care, environmental protection, resource development and increase in human per capita index. The policy must ensure the engagement of a large part of the nation's citizenry especially the youth in productive activities for the attainment of national objectives and global competitiveness.

Rather than seek solace in violent crimes, socio-political as well as communal clashes as a result of idleness and low standard of living. The attainment of the above policy can be largely rooted on implementing a wellstructured, developed and productive TVET background. Ezenwafor (2015) reported that over three decades ago Nigeria adopted TVET in the school system, from secondary to tertiary levels, with huge government and foreign investment in training teachers at local and foreign institutions. Despite this, the nation is still struggling with rising unemployment, even among TVET graduates as well as universities dependent on professional degrees. Umunadi and Uwameiye (2015) stated that the effect of TVET on human resource 
development in Nigeria was not adequately felt. This ugly truth as paradoxical as it may sound makes the relevance of TVET questionable. Take for instance, the current operating Nigerian curriculum at the secondary school level has TVET integrated in basic technology (FRN, 2013). In this curriculum, instructions are arranged in such a way that students are taught computer, farming skills, typing and shorthand skills among other at the junior secondary level while at the senior secondary level.

They are taught Building/Wood work, Metal work, Electrical/Electronics, Automobiles, technical drawing, amongst others. In revitalizing TVET in schools, this will provide students with opportunities to improve themselves in their overall competency, particularly in line with future or current occupations. The dynamics in a country's economy has the role of preparing students/young individuals for future jobs where TVET have crucial roles to play if well implemented. TVET still face the challenge of inadequate funding, low staff motivation, lack of modern facilities and personnel, which is needed and robs the nation of development which would have been possible through the contributions of TVET graduates. The study of Asogwa and Diogu (2007) maintain that Nigeria urgently needs to be directed to being self-sufficient and able to sustain the livelihood provided by TVET. Unfortunately today, the reality is not as it should be. It has been observed that students' enrolment in TVET courses have been decreasing exponentially in colleges, polytechnics and universities (Aina, 2008). Putting too much stock strictly on University education has hampered the opportunities of those technically gifted in Nigeria and less adept at academics (Ojimba, 2012).

A lot of "expatriate engineers" receive large sums of money from the Nigerian government for road construction and other technical services but they are products of vocational colleges from other nations. The issue of TVET in Nigeria is not taken seriously, so the need to reinvent TVET in Nigeria is paramount. The poverty level of the country increased to $70 \%$ to the point that a lot of Nigerians standard of living is less than a dollar a day. According to a news report by the World Poverty Clock, Nigeria has overtaken India as the country with the largest number of people living in extreme poverty. The report states that extreme poverty in Nigeria is growing by six people every minute, the highest number in the world. At the end of May 2018, the survey showed that Nigeria had an estimated 87 million people in extreme poverty, compared to India's 73 million (www.dailypost.ng, 2018). The institutions of TVET in Nigeria do not possess the machinery and tools needed to properly train individuals in the acquisition of required skills organizations look out for. The problems of TVET are quite enormous; Hence, the need to resuscitate TVET in the curriculum. Nigeria is not utilizing TVET in achieving national goals and as such not reaping the many benefits of TVET like other countries of the world that have well developed and implementable TVET objectives.

\section{Technical Vocational Education and Training Curriculum Development in Nigeria}

At the advent of the colonial masters in Nigeria, different indigenous communities and cultures had developed their own system of informal, formal and TVET system. There was in existence in ancient times what is referred to today as the "Saber-tooth curriculum" whose main objective was teaching of the knowledge and skills needed for survival. In the past, TVET was done through the system of apprenticeship, whereby youths usually at a tender age are attached to masters of crafts and learn the trades; acquire skills like textile design and dyeing, carving, foundry, blacksmith, masonry and carpentry, among others. This system saw apprentices spend years with their masters/trainers. The duration of such apprenticeship was largely dependent on the trade specialised in, the exposure, competence and skill of the master and lastly on the apprentice performance and overall capacity. When the training ends, the apprentice is given assistance by the master or immediate family to procure equipment's and tools to commence his or her own trade. Where the apprentices over the years have become a master in their respective fields, they acquire apprentices to work under them. Furthermore, Umunadi and Uwamieye (2015) observed that reflecting on the history of TVET in Nigeria, it is observed that the curriculum for education is subject to political and social influences directed to achieve any social or political needs of the government.

The commencement of British rule in Nigeria, administrators and traders where shared by the colonial missionaries and curricula were employed and modified to achieve the colonial master's vested interests. Nigeria gained independence in 1960 and afterward, it was discovered that the colonial education curriculum did not suit the Nigerian people, because it did not produce the manpower needed to develop the society. The sustainability of youth empowerment was not achieved with the curricula introduced by the colonials' and in 
solution Nigeria introduced the 6-3-3-4 system of education (Ojimba, 2012), the goal of designing the 6-3-3-4 system to get individuals prepared and useful to society (FRN, 2013). The choice of any TVET curriculum is focused on the role of technical colleges in society. This indicates that curricula need to be designed to fit society's need as stated in its national objectives. The Federal Government towards realization of a better citizenry for the nation decided to implement the 6-3-3-4 policy on education in order to achieve sustainable youth development and empowerment for the nation as a whole to foster change. However, the implementation of this policy has been a large far-cry from the intended objective. This is because as observed by Eze (2013), TVET does not contribute immensely in reducing unemployment, hunger and poverty in Nigeria due to the problems it faces.

Challenges of Technical Vocational Education Training in Nigeria: One of the prominent challenges identified by Oranu (2004) in Odu (2013) is the lingering issue of the Curriculum of TVET. Oranu added that the curriculum of TVET with practical content is generally organized into an average of $67 \%$ for the theoretical classes and 33\% for workshop. FRN (2013) makes provision for the range of subjects to be offered in technical colleges. TVET curriculum has to, as a matter of necessity is concerned mainly with practical activities than merely theoretical classes. However in reality, the opposite is the case as the curriculum in practice in secondary schools, technical colleges and universities actually focus on theoretical learning inside the four walls of the classroom than practicing these theories learnt (Odu, 2013). To reinvent TVET, the youth must be taught practical aspect of TVET; exposed to the equipment at the work places. In other words, the slow growth of technology and industrialization is largely credited to the continuously disparity between the current Nigerian level of industrialization (consisting majorly of unskilled labour, semi-mechanized practises) and the current trends in science and technological advancement.

This can be traced to TVET's inability to use technological and scientific ideas and effectively implement such ideas to promote technology. Lack of funds available to TVET establishments makes it difficult to pay the salaries of staff. It leads also to teachers being let go or forced to retire ahead of time. Thus, suggesting the need to refurbish or reinvent the entire TVET curricula in Nigeria. It is noteworthy that though such refurbishment of the curricula may not necessarily be the only remedy to producing highly literate technical and vocational experts for the industry but it will put Nigeria on the path of rapid industrialization and corresponding economic growth. This is only attainable when solutions are provided to some of the challenges faced and effectively and adequately equipping the youths with much needed skills to live daily (Okoye, 2010). The study of Olunloyo (2002) stated that among the issues causing the changes in the appropriate design of TVE curriculum is the issue of students being prepared for the changes from dist or cruel mode of production to the use of Information Communication and Technology (ICT) standard in scientific and technological practices of production and industrialization. Ojimba (2012) recognized 6 challenges the curricula currently face in Nigeria.

These challenges are highlighted below:

- The approach to teaching follows the traditional techniques used to transfer knowledge via lecturers reading out loud to students, they put down notes. The system of education in Nigeria continues to put consideration on the value of this mode of teaching.

- The following are inadequately provided such as entrepreneurial skill development, concept of business management, social science and humanities.

- The curriculums are estimated to be overloaded and too academic with intellectual content in pure mathematics and science without emphasis on technology and basic engineering.

- There is limitations to how competent support staff and indigenous teaching with adequate experience with technology.

- The inadequacy of textbooks and the available textbook being from foreign countries are filled with examples that do not have local content.

- The model of the curricula is foreign which was developed under good a condition (training opportunities, infrastructure, equipment and staff) that is not available in developing nations. Other salient challenges/factors associated with the ineffective development and implementation of curriculum on technical and vocational education in Nigeria as examined by Umunadi and Uwameiye (2015) are as follows: 
Inadequate Funding of TVET: TVET has undoubtedly affected the Nigerian society particularly with regard to the products of the training program that continually contribute their part to developing the nation via manufacturing institutions (Odu, 2013). Lack of funds for vocational establishments has resulted in the increase in graduates who are half-naked due to lack of funds to maintain and build labs, workshops and equipment (Umunadi and Uwameiye, 2015). Staffing in TVET is commonly inadequate due to inadequate funding. The rate of employee turnover is high as a result of improper remuneration and as such, staff are not attracted towards teaching but strive to go into other fields where economic opportunities are better and this is sometimes located abroad or in industries. Therefore, unqualified and inexperienced TVET teachers given employment reduce the standard of education, leading to the inability to achieve the goal of TVET (Agbionu, 2003). Additionally, Momoh (2012) state that the lack of commitment on the part of government and insufficient funds weakened TVET in Nigeria a direct consequence of this is that while the number of TVET institution is dwindling that of general education is growing in bounds (Momoh, 2012).

Inadequate Facilities: In Nigerian Universities, majority of TVET departments do not have laboratories or workshop space, let alone useable equipment and where they exist, they are grossly inadequate, as the workshops only have items or equipment that were provided when the departments were first established of which most of them are already obsolete or grounded (Ojimba, 2012). It is quite unfortunate and surprising too to know that most TVET departments still depends on engineering workshops and lecturers to teach technical education concepts in this 21st century. The available facilities, programme as at today are inadequate quantitatively and qualitatively and besides they are out-dated. Oryem-Origa (2005) opined that only $40 \%$ of institutions of Higher Education in Nigeria have laboratory or workshop space for TVET programmes. The remaining $60 \%$ do not have laboratory or workshop, spaces and this has resulted to the low quality of technology programmes in Nigeria higher institutions. He also observed that the few schools that have laboratories, experience acute shortage of laboratory equipment and supplies. The shabby performance of TVET graduates is no longer news as very important projects in the country, particularly, the construction industry are now run by technicians and craftsmen from neighbouring West African countries (Nworlu-Elechi, 2013).

Brain Drain: Brian drain denotes lecturers of technical education and TVET teachers' movement and this is vital for the technological and socio-economic development of the country. The conclusion is that the situation is partly the reason it has been very difficult to carryout experiments effectively for students. This has also made teaching and research in science and technology difficult and therefore the country was producing insufficient and ill prepared TVET graduates for driving the technological and socio-economic development of Nigeria. This is in from one university to another, one profession to another where conditions of work are better. The study states that about " $45 \%$ of all Nigerian professionals including technical educators have left the Nigerian shores over the years. Between 1997 and 2007 alone, Nigeria lost over 10,000 middle level and high level managers to the western economies". Nigerian lecturers numbering 500 continue to move each year, to foreign nations.

Training and Retention of Staff: The need for on-going training of staff ensures continuous enhancement in improving the quality of their output. Staff can be trained overseas or locally. Training that take place within the nation is less costly compared to training overseas but less comprehensive due to inadequate literatures, facilities, and challenges that arise from the need to meet the required demands. Education abroad requires a lot of foreign exchange but there is an encouraging atmosphere for achieving success in a record time. Overtime, however, it has always been difficult to get the trainees back to their respective countries after their research was completed. The salary and service benefits paid to TVET teachers in Nigeria are about the lowest in the world (Ojimba, 2012). This leads them to migrate to other countries for better pay.

Apathy of Political Office Holders/Law Makers: Education generally including TVET programme has been grossly neglected in Nigeria. TVET educators have the greatest challenge of convincing the law makers on the reason they should give priority attention to the programme in resources allocation. Many options of getting positive results have been advocated at different for a namely; lobbying, participation of TVET educators in governance, wooing and among others, yet the government is still playing a lopsided attitude to the proper development of the programme in Nigeria. Therefore, Nigeria will ever remain a technologically backward and dependent nation if this negative attitude and trend is not reversed. 
Value System in Nigeria: A lot of emphasis in Nigeria has been put on university certificates without regard to if the holder has the necessary knowledge and skills to defend it. In developed society contrarily, individuals who possess technical skills and qualifications are regarded highly. As such, this country's value system depends on the skill, knowledge and competence of an individual and not the certificate they possess. TVET graduates in public service are discriminated against and their future career prospects are restricted. Given this, parents and secondary school leavers tend to favour university educations to TVET (NworluElechi, 2013). The benefit of TVET cannot be an over-statement to say that TVET drives economic growth. A war cannot commence where there is army. Similarly, Nigeria cannot achieve economic growth short of having a TVET established equipped with the best resources. This is what is missing in the development of Nigeria's policy (Dike, 2009) given this, Nigeria need to invest significantly education, with emphasis on TVET (Ojimba, 2012). Now Nigeria will start implementing policies to reposition TVET for successful competition in the evolving global market. UNESCO, the World Bank, among other organizations, noted that revitalizing this sector is one of the ways in which young people can boost their economic opportunities.

Nigeria Labour Congress and the affiliated Unions, churches, banks could also give their support in this regards by setting up functional vocational training centres in the Local Government Areas from where the people could go and acquire some technical and vocational job skills. Furthermore, upgrading the skills of the workers consequently would improve their productivity and attract better pay packages (salaries, allowances and other benefits). There is now the urgent need for all agencies and organizations involved in National Empowerment and Development Strategy (NEEDS) and Self Employment and Entrepreneurial Development System (SEEDS) to create more awareness about TVET and job training in their programmes for economic growth and development strategies aimed at poverty reduction, job creation and global competitiveness. Paying lip service by Nigerians in this regard will not solve the problem a policy by the World Bank in 1991 states that developing skilled labour is a vital factor for any nation's development.

Getting the private sector involved, training institutions and employers of labour can provide the best medium in terms of efficiently and effectively developing the skill of the labour force. Till now, it seems the Nigerian Government paid deaf ear to the warning. Also on the $13^{\text {th }}$ September 2018 the World Bank drew attention to the ugly trend, they noted that there is skills gap between what the institutions are producing and what the industries are demanding so in conjunction with the Federal Ministry of Education through NBTE organize a workshop in Abuja for Innovation Development and Effectiveness in the Acquisition of Skills (IDEAS) for the national economy in Nigeria. The IDEAS project is aimed at deviating from the current operating supply driven curriculum to a demand driven one, where the government shall produce graduates that are well skilled and relevant to the economy. So there is urgent need to address the problems associated with curriculum development and implementation in TVET in Nigeria with the view of reinventing TVET for global competitiveness.

\section{Global Competitiveness}

The world is a global village. Having a competitive advantage at an international level is fundamental for Nigeria as a developing nation. Providing her citizens with functional education that would guarantee international competitiveness should be the in-thing for any nation whose world of work is shrinking and as a consequence, her citizenry have to look beyond the local workplace for employment and rendering of services. Doing this will involve a thorough redefinition of the concepts of education, schooling and curriculum development and design. To this end, the World Economic Forum (2014) identified several pillars that mark the competitive strength of countries as institutions, infrastructure, macroeconomic environment, health, education, technological readiness, operational diversity and innovation among others. Each of these components has a different degree importance and they are interactive with one another. Among them, education and technological readiness are at the core; they increase a nation's productivity in terms of competitiveness. The World Economic Forum (2016) defined competitiveness as the set of institutions, policies and factors that determine the level of productivity of a country. The Forum opined that competitive economies are those that are most likely to be able to grow more substantially and inclusively, meaning more likelihood that everybody in the society will benefit from the fruits of the economic growth. In the context of education, global competitiveness has to do with global marketability of education and the ability of the education system of a country. 
To meet global or international standards and produce human capital that has the capacity to innovate and compete effectively in the ever dynamic and emerging world of work. Thus, the products or graduates must have the requisite competences, knowledge, skills, attitudes and values that are substantially comparable with global benchmark and provide the nation the requisite innovation for development. This is because the emerging world of work has increased channels and access to global customers through enhanced communications, improved transport system, centralized financial system and globalization with its attendant reduction (in most cases removal) of barriers. This has increased mobility, thus making knowledge a global commodity. TVET is the organized and sustained instruction designed to communicate a combination of knowledge, skills and understanding valuable for all activities of life. It involves the leading out of the potentials of the individual recipient and the acquisition of skills, knowledge, attitudes, values and competences to enable an individual contribute effectively to his/her own as well as societal development. TVET is a potential tool for imparting scientific and technological skills as well as liberate the minds of the individual. There is usually a high correlation between the quality on man power and the overall level of development of any country and her system of education. The degree of development of a country is a product of her educational system. Today, Nigeria as a developing country is faced with unemployment issues.

Which make employment stiffly competitive for both the skilled and the unskilled in the light of the above, the World Economic Forum (2018) advised governments at all levels on the need to prioritise investments in human capital in order to improve Nigeria's competitiveness in different spheres of life. This implies that it is essential for Nigeria to invest in quality and functional education (TVET) that will equip her present and future workforce with the requisite skills that are required for the emerging world of work. Learners and students are prepared by TVET for professions with mostly practical or manual activities, originally not related to academics and focused on a particular vocation, occupation or trade. As opposed to overall education, TVET learning is focused on "applied" instead of "academic", skills instead of knowledge and practice instead of theory. Therefore, there are a number of problems faced by TVET because of the high rate of global unemployment. To reach its stated goal, TVET in Nigeria should be strengthened and as such, it should not be left to the government alone but private partnership should be sort out as well to help the nation achieve its estimated goal the examination of how private and public partnership can be developed and implemented in TVET curriculum.

Concepts of Technical Vocational Education and Training and Public/Private Partnership: The economic system of a country is made up of private and public sector. The private sector is operated majorly by companies and individuals with the intention of making profit. The private sector is made up of small businesses, corporations, as well as profit and non-profit organizations; the end beneficiary of the services offered by the private sector is the general public who purchase the goods and services provided by the private sector for consumption. A coalition between the private/public sector and TVET is regarded to as partnership. Partnership can be defined as the agreement between parties who agree to form an alliance in order to further their own interests. The alliance can be between organizations combined, local community, employees and their representatives, professional association, schools and government. TVET establishments can form an alliance with private/public in order to overcome their limits and this is referred to as PublicPrivate Partnership (PPP). The PPP Policy (2012) referred to Public-Private Partnership as a long standing contract between the private and public sectors where the ability of the parties involved should be focused on risks and reward, offering services or products through adequate allocation of resources, building and operating infrastructures, financing and designing. PPP is a collaboration and arrangement that private and government bodies enter into to offer services to individuals based on terms already established (Oviawe, 2018). Agence Francaise De Development (AFD) (2014) viewed PPP as that consisting of bringing together public authorities and private stakeholders to devise, finance, build, manage or preserve a project of public interest.

The public/private partnership is a broad term for the association formed between public and private bodies, regularly with the goal to introduce resources in the private sector and expertise to assist in the provision and delivering of public sector services and assets. In context, public/private partnerships in TVET refer to different arrangements between the private and public sector participants, where the private sector brings to the table services and infrastructures the public sector ought to provide without putting their profit in 
jeopardy, the main goal of this is to offer practical training opportunities for skill development for learners. There are different types of partnership, formal and informal partnerships. Formal partnerships refer to an agreement between parties where each of their obligations and roles are well spelt out through a written agreement while an informal partnership refer to agreements between parties whereby obligations and roles between parties are verbally agreed upon. The major feature of PPP include; private sector arrangement through delegation of some project functions (delegating the role of finance and asset, rehabilitate, maintain, operate, develop/expand, build and design to private sector parties); requires private sector entities take noteworthy risks in carrying out this functions assigned, i.e. the revenue of private parties depends on performance (quality and quantity of output supplied or asset availability); management or operation of assets or services is within a time frame; and involves infrastructures and assets provided for the benefit of the public as output has the factor of facilitating services provided by government of sovereign nations to its citizens (PPP Policy, 2012). The contract with the private sector has the benefit of a time frame that comes after the agreement has been made.

Need for Public/Private Partnership in TVET for Global Competitiveness: The neglect of TVET regrettably serves to obscure global development. Nations over the world have attempted to combat unemployment issues. The volume of graduates unemployed and in the labour market is distressing and the distress is more pronounced due to the quality of graduates. The increase in unemployment rate among youths contributes to the increase in social vices and poverty rate facts gotten from the federal Bureau of statistics and National Manpower Board show that the population of youths in Nigeria is 80 million which signifies $60 \%$ of the entire population. The number who are underemployed is 1.6 million while those unemployed is 64 million while over 112.5 million youths in the country are below the poverty line (National Bureau of Statistics, 2015 in Oviawe, 2018). TVET is no longer seen as being solely in the realm of educational institutions but is increasingly involving workplaces, private individuals and a variety of other nongovernmental and community organizations (Australian National Training Authority (ANTA), 2003 in Oviawe, 2018). ANTA postulated that the increase in competition changes the makeup of the economy workplace and occupational changes significantly influence the nature of activities in the workplace. The indication shows that the level of skill possessed by current and future employees need to be developed continuously. Given this, learning in the work place (formal/informal) is becoming a vital role in training and education in the workforce. Therefore, partnership is needed. The importance of PPP in TVET is highlighted due to the ineffectiveness of TVET institutions and programmes and low quality of output (Oviawe, 2018). PPP is unavoidable and the difficulty in finance makes it harder for the government to pay the rather high cost involved.

Ways for Reinventing TVET Appropriate Strategies for Curriculum Development and Implementation in TVET for Global Competitiveness: In reinventing the TVET system to empower the youth to meet the changing needs of the economy, market and the expectations of the society, the following are suggested:

- Students who graduate from TVET establishments are to be equitably and adequately rewarded. The contradiction between general studies and technical certificates need to be eliminated by changing the mind-set and thinking as well as through policy.

- The majority of the informal sector that produce artisans need to be monitored and regulated. The licensing of these institutions will allow them award apprentices with certificate when they complete their training on government's behalf. Doing this, fraudulent activities can be detected and isolated.

- The employer of labour and government should remove urgently the contradiction that is between TVET institutions and university. Polytechnic establishments should be set up to grant degrees. Highly qualified students will be attracted and TVET will be encouraged to send qualified teachers between the two systems.

- The TVET institutions need to commence teaching industry focused employment opportunity for those leaving secondary schools. This offer dropouts sufficient opportunities.

- TVET curriculum should be set up with the demands in the work place as a guide.

- When TVET industries and institutions collaborate, the association will allow them understand and appreciate their needs and offer solutions that will benefit society globally.

- TVET is needed to build good linkage and relationship with similar organizations outside the country that promotes the enhancement of technology and cross fertilization of thoughts. By so doing, TVET 
institutions exchange programmes, get access to new innovations and other advantages that is available to the institutions where TVET programmes are properly developed.

- $\quad$ TVET requires proficient and skilled teachers. The preparation of the teachers should be prioritised. Regular training for technology teachers to update their skills and this is to keep up with global changes in technology in the industry.

- Adequate resources should be allocated to TVET. Insufficient funding affects the provision of necessities like training materials, relevant textbooks and well-equipped laboratories.

\section{Conclusion}

In Nigeria the TVET system requires urgent attention. Priority focus has to be paid to investing in TVET. Since no country can cope favourably with cheap and unskilled labor in the changing global marketplace. The lawmakers in Nigeria and all stakeholders in the education sector must learn from their foreign counterparts as attempt is made to invest more in TVET framework to meet the ever-evolving global competitive position in technological development. The lack of consultation would lead to the teaching of obsolete curricula material and teaching methods, the majority of students studied through lectures and academic test books, and are limited opportunities for gaining practical experience through the use of machinery, equipment and practical techniques associated with the field to teach TVET innovation through lack of qualified teachers to teach TVET innovative; entrepreneurships and job skills; also serious shortage of skilled workers and technicians in the growth sector of petroleum, gas, agriculture, manufacturing, solid minerals and ICT sector are not left out.

\section{References}

Agence Francaise De Development. (2014). Public-Private Partnership in vocational training: Taking stock of AFD's experience and strategic recommendations.

Agbionu, E. O. (2003). Introduction to International Economics. Lagos: Clemeddy Educational Services.

Aina, O. (2008). Promoting technical education for the achievement of Nigeria's 20:20:20 vision. Summit on Repositioning Nigerian educational system for the achievement of the national 20:20:20.

Alvior, M. G. (2014). The meaning and importance of curriculum development. In simply educate me.

Asogwa, O. \& Diogwu, G. O. (2007). Vocational and Technical Education in Nigeria in the 21st Century. Journal of the Nigerian Academic Forum, 12(2), 102-109.

British Council. (2017). The role of TVET governance at sub-national levels. Simon Perryman and John Perryman of Perryman, Yeandle and Associates Ltd.

Dike, V. E. (2009). Technical and Vocational Education Key to Nigeria Development. Printed 10 th June 2015 unpublished online source.

Eya, P. E. (2006). Fundamentals of Curriculum Development. Enugu: J.T.C. Publishers.

Eze, C. P. (2013). Empowering the Youth through Technical and Vocational Education: A Panacea for Sustainable National Development. Unizik Orient Journal of Education, 7(1), 59-64.

Ezenwafor, J. (2015). Rating of strategies for transforming technical vocational education and training for the $21^{\text {st }}$ century by tertiary institutions lecturers in South-East Nigeria. International journal of education policy research and review, 2(7).

Federal Republic of Nigeria. (2013). National policy on education. Lagos: NEDRC Press. Merriam-Webster Dictionary.

Momoh, O. A. (2012). Revitalization of Technical Education in Nigeria as a Vehicle for Transformation. Proceedings of COREN 21stEngineering Assembly, 53-81.

Nworlu-Elechi, O. (2013). Technical and Vocational Education for National Transformation. Proceeding of $1^{\text {st }}$ ASUP Zone D National Conference, 21-37.

Odu, K. O. (2013). Reappraising the Work Skill Requirements for Building Technology Education in Senior Secondary Schools for Optimum Performance in Nigeria. Proceedings from Africa Society for Scientific Research (ASSR): The First International Technology Education and Environment Conference Human Resource Management Academic Research Society.

Ojimba, D. P. (2012). Vocational and Technical Education in Nigeria: Issues, Problems and Prospects Dimensions. Journal of Education and Social Research, 2(9), 217-237. 
Okoye, E. K. (2010). Enhancing quality on educational practice and instructional delivery by teacher technology vocational education in Nigeria. Africa research review. An International Multidisciplinary Journal Ethiopia, 4(2), 354-370.

Olunloyo, V. O. S. (2002). The Challenges of Globalization for the Design of Technical Curriculum in Developing Countries. Lagos: University of Lagos Press.

Oranu, R. N. (2004). Vocational and Technical Education in Nigeria.

Oryem-Origa, S. O. (2005). Vocational Education and Manpower Development. Lagos: Nigeria Vocational Monograph.

Oviawe, J. I. (2018). Revamping technical, vocational education and training through public-private partnerships for skill development. Maker ere journal of higher education, 10(1), 73-91.

The PPP Policy. (2012). Shaping new partnership for national development and institutional framework for the implementation of a public-Private Partnership programme for the government of Jamaica.

The World Economic Forum. (2014). Global competitiveness index dataset.

The World Economic Forum. (2016). The global competitiveness report.

The World Economic Forum. (2018). World Economic Forum Annual Meeting.

Umunadi, E. K. \& Uwameiye, R. (2015). Technical education graduate skill development as perceived by employers in institution and industries in Delta State. Studies in Education, 15(1) 90-97.

www.dailypost.ng. (2018). Retrieved on $22^{\text {nd }}$ June, 2018. 